\title{
Associations of Maternal Complaints to Levator Ani Muscle Trauma Within 9 Months After Vaginal Birth - A Prospective Observational Cohort Study
}

\author{
Nina Kimmich ( $\nabla$ Nina.Kimmich@usz.ch ) \\ University Hospital of Zurich, Department of Obstetrics \\ Jana Birri \\ University Hospital of Zurich, Department of Obstetrics \\ Anne Richter \\ University Hospital of Zurich, Department of Obstetrics \\ Roland Zimmermann \\ University Hospital of Zurich, Department of Obstetrics \\ Martina Kreft \\ University Hospital of Zurich, Department of Obstetrics
}

\section{Research Article}

Keywords: Levator ani muscle, avulsion, vaginal birth, pelvic floor, prolapse, urogynecological complaints

Posted Date: May 6th, 2021

DOI: https://doi.org/10.21203/rs.3.rs-477724/v1

License: @) (7) This work is licensed under a Creative Commons Attribution 4.0 International License. Read Full License 


\section{Abstract}

\section{Background}

Pelvic floor trauma in form of partial or complete avulsions of the levator ani muscle (LAM) affects 6-42\% of women after vaginal birth and can cause tremendous long-term morbidity. Many studies assessed morphological pelvic floor trauma after childbirth, but lacked to evaluate women sassociatedsh or $t$-termcompla $\int$ s. $A \propto$ erassessmentoftrauma and $\subset$ jectivecompla $\int$ safterbirthcodhelp $\rightarrow$ assesspossib $\leq$ associationsb s daily life. Therefore, we aimed to assess women`s complaints within the first months after birth in association to their LAM trauma.

\section{Methods}

Between 3/2017 and 4/2019, we prospectively evaluated vaginal births of 212 primiparous women with singletons in vertex presentation $\geq 36+0$ gestational weeks for levator ani muscle (LAM) trauma by translabial ultrasound, for pelvic organ prolapse by clinical examination, and for urogynecological complaints using questionnaires 1-4 days (P1), 6-10 weeks (P2) and 6-9 months (P3) after birth. Women`s complaints were evaluated for P1-P3 according to their LAM trauma state.

\section{Results}

At P1, $67 \%$ of women showed an intact LAM, whereas $14.6 \%$ presented a hematoma, $6.6 \%$ a partial avulsion (PAV) and $11.8 \%$ a complete avulsion (CAV). At P2, 75.9\% showed an intact LAM, 9.9\% a PAV and $14.2 \%$ a CAV. At P3, 72.9\% of women with a LAM trauma in P1 and/or P2 were assessed, with $21.6 \%$ being intact and $39.2 \%$ having a PAV and CAV respectively. Obstetrical and baseline characteristics differed slightly between the groups. When comparing the time before and during pregnancy with the time after childbirth, birth itself affected women`s complaints in all LAM state groups, but the presence of a LAM trauma, especially a CAV, had more negative effects.

\section{Conclusions}

Vaginal birth changes the anatomical structure of the maternal birth canal and genital tract, and it alters women`s perceptions and body function. In our study, LAM trauma did not change these effects tremendously within the first months additionally. Therefore, other maternal, fetal and obstetrical factors need consideration for the explanation of maternal complaints, in addition to long-term effects of trauma and dysfunction of the LAM and other birth canal structures.

\section{Introduction}

Pelvic floor trauma in form of partial or complete avulsions of the levator ani muscle (LAM) affects $6-42 \%$ of women after vaginal birth (1-7). LAM defects, especially complete avulsions of the LAM, are associated with genital prolapse in later life and can cause tremendous short- and long-term morbidity in affected women, including pain, sexual dysfunction, incontinence, prolapse and psychological distress (8-14). In the past years, many studies were published about the assessment of morphological pelvic floor trauma after childbirth. Hereby, LAM avulsions were diagnosed most reliably by 4-dimensional (4D) translabial ultrasound (TLUS) as the standard diagnostic tool (11, 15-18). However, little emphasis has been laid on women scompla $\int$ sassociatedwiththesechan $\geq s$, especiallywith $\in$ thefirstmonthsafterbirth. A $\propto$ erassessment and documentationoftrauma and of s complaints after birth could help to assess possible associations between morphological changes and subjective complaints and their relevance to women`s daily life in order to identify women of risk for impairment later on (19). Therefore, the aim of our prospective study was to assess different LAM trauma states of primiparous women by 4D ultrasound examination and to evaluate their subjective complaints by questionnaires at different times within 9 months after birth according to their allocation to different LAM trauma states.

\section{Material And Methods}

We performed a prospective observational cohort study at our tertiary care center between $3 / 2017$ and $4 / 2019$. Nulliparous women $\geq 18$ years of age with singleton pregnancies in vertex presentation $\geq 36+0$ gestational weeks (gw), who planned a vaginal birth in our institution, were recruited in advance. We excluded multiple pregnancies, deliveries before $36+0 \mathrm{gw}$, planned cesarean sections, fetal transverse or breech positions, fetal malformations, maternal connective tissue diseases, maternal history of vaginal, perineal or vulvar surgery, maternal history of pre-existing daily urine or anal incontinence and difficulties in communication due to insufficient communication in German or English. Clinical data were obtained from the institutional obstetric database (Perinat version 6.1.9.45).

First, all women that finally gave birth vaginally were evaluated for their LAM trauma state 1-4 days (P1) and 6-10 weeks after birth (P2). LAM state was assessed by $4 \mathrm{D}$ translabial ultrasound by two well-trained pelvic floor sonographers. Women were asked to empty their bladder before the examination and were placed in lithotomy position. A covered 4D abdominal probe of 4 to 7-MHz (Voluson S10, GE Healthcare, Zipf, Austria) was placed between the labia at the posterior fourchette. Acquisition of $4 \mathrm{D}$ tomographic volumes and their interpretation were performed as described by Dietz et al $(15,17)$. TUl imaging was performed with 2.5-mm slice intervals, from $5 \mathrm{~mm}$ below to $12.5 \mathrm{~mm}$ above the plane of minimal hiatal dimensions. All images were reviewed and optimized in a second step with the software 4D View 7.0 (GE Healthcare, Zipf, Austria). Two reviewers then classified LAM states into intact, hematoma, partial avulsion (PAV) or complete avulsion (CAV) $(15,16)$. A partial avulsion was stated, when there was continuity of some part of the muscle to the ramus inferior of the os pubis, and a complete avulsion, when there was a complete discontinuity of the muscle to the pelvic sidewall. An-/hypoechogenic lesion inside the muscle with intact muscle tissue on both sides around was attributed to a hematoma. All women diagnosed with a LAM trauma (hematoma, PAV, CAV) at P1 and/or Loading [MathJax]/jax/output/CommonHTML/jax.js nonths after birth (P3). 
Second, women additionally underwent an urogynecological examination for clinical pelvic organ prolapse at P2 and P3, quantified by the POP-Q classification system of the International Urogynecological Association (POP-Q stages 0-4). No such an assessment was performed directly after birth at P1 due to womens' discomfort by any kind of birth tears, hematoma or swelling. Women with POP-Q stage 0 and 1 of the anterior genital compartment were assigned to the "no anterior prolapse" group, women with POP-Q stage 0 and 1 of the posterior compartment to the "no posterior prolapse" group and women with POP-Q stage 0 and 1 of the central compartment to the "no central prolapse" group. Women with POP-Q stages $2-4$ of the anterior, posterior and central compartment were assigned to the "anterior prolapse", "posterior prolapse" and "central prolapse" group respectively for final evaluation. This allocation was used as a clinical relevant prolapse is generally accepted with POP-Q stages 2 and higher.

To assess subjective impairment and complaints after birth, every woman was asked to complete a questionnaire with multiple questions about their urogynecological condition at each assessment period (Table 1). At P1, women were asked to answer questions about their condition at either the time before and during pregnancy respectively (Table 1, No.1-7) to control for pre-existing urogynecological complaints and disorders, with 3 possible answers ("never", "sometimes" or "'daily/always"). Then, they were asked 12 questions (Table 1, No. 8-19) about their current urogynecological condition. The same 12 questions were asked at the other two assessment periods P2 and P3. Women taking part in the assessment period P2 and P3 additionally completed another nine questions (Table 1, No. 20-28).

Part of the questions at P1-P3 had to be answered with either "yes" or "no", others with a graduation from 1 to 7 on a scale. The graduation 4 in the middle of the scale represented the situation of "unchanged" after birth compared to the time before pregnancy. The graduation 1-3 to the left represented "less often/tighter/weaker/drier/reduced", for example "little less" (grade 3), "less" (grade 2) and clearly/much less" (grade1). The graduation to the right side with 5 to 7 represented "more often/wider/stronger/wetter/better/increased", with for example "little more" (grade 5), "more" (grade 6), clearly/much more" (grade 7). For final analysis of the questionnaires, the answer grades 1 and 2 were summarized as "less often/tighter/weaker/drier/reduced", the answer categories 3 to 5 as "unchanged" and the categories 6 and 7 as "more often/wider/stronger/wetter/better/increased".

The answers of women to the mentioned questions were evaluated for the different periods P1-P3 according to their allocation to the different LAM state groups. ("intact LAM" vs. "hematoma" vs. "PAV" vs. "CAV" at P1, "intact LAM" vs. "PAV" vs. "CAV" at P2 and P3 respectively).

Statistical analysis was performed using the statistical software package SPSS version 25.0 (IBM SPSS, Armonk, New York, USA). Student's t-test was used to compare continuous variables and chi-square test was used for categorical variables.

The study was approved by the Local Ethical Board of the District under the registration BASEC-No. 2016 - 00908. Additionally, all study participants gave their written informed consent for the study.

\section{Results}

362 nulliparous women gave their written informed consent for participation, of whom 150 women had to be excluded from the study later on. The reasons for exclusion were birth by cesarean section, fetal breech position at birth, preterm birth $<36$ gestational weeks, delivery at another hospital, immediate transfer to another hospital due to missing capacity in our neonatal department, because women were missed of being a study participant postpartum, absence of both ultrasound investigators at P1, women's decision to withdraw from the study, because they did not show up for the ultrasound evaluation after 6-10 weeks or they refused to fill out the questionnaire at P1. Finally, 212 data sets remained for analysis (Fig. 1).

\section{Levator ani muscle state}

The distribution of the LAM states of the study cohort at the P1-P3 can be seen in Fig. 1.

At P1, 67\% ( $n=142)$ of women showed a completely intact LAM. A hematoma inside the LAM was diagnosed in $14.6 \%(n=31)$, a PAV in $6.6 \%(n=14)$, and a CAV in $11.8 \%(n=25)$ of women.

At P2, 75.9\% $(n=161)$ of women showed an intact LAM, as in addition to the 142 women with intact LAM at P1 54.8\% of women with an initial hematoma and $14.3 \%$ of women with an initial PAV had an intact LAM at P2. A PAV was found in $9.9 \%(n=21)$ of women at P2, as $64.3 \%$ of PAVs at P1 remained as a PAV, and $35.5 \%$ of hematomas and $4 \%$ of CAVs at P1 turned into a PAV. A CAV in P2 was diagnosed in $14.2 \%(n=30)$ of women, as $96.0 \%$ remained as a CAV, and $9.7 \%$ of hematomas and $21.4 \%$ of PAVs in P1 changed into a CAV at P2. None of the hematomas from P1 persisted at P2, as all of them resolved.

Of the 70 women with any kind of LAM trauma in P1 and/or P2, 53 women (75.7\%) were available for the examination at P3. 2 of those had to be excluded due to poor ultrasound image quality and impossibility to assess the LAM state correctly. Therefore, 51 women showed a clear LAM state at P3, with $21.6 \%$ ( = 11) being intact, and 39.2\% $(n=20)$ presenting with a PAV and CAV respectively.

\section{Baseline demographic and obstetric data}

The baseline demographic and obstetric data of the study cohort are shown in Table 2.

Significant differences in the baseline characteristics of the different LAM state groups at P1 were found for the birth mode, epidural anesthesia rates, episiotomy rates and the duration of the second stage of labor. Women with a PAV or CAV had more often a vacuum-assisted vaginal birth $(p=0.022)$ than the others. Women with a hematoma or CAV had less often an epidural anesthesia $(p=0.013)$. Women with any kind of LAM trauma had twice as often an episiotomy as women with intact LAM $(p=0.001)$ and had a longer duration of the second stage of labor $(p=0.018)$.

Loading [MathJax]/jax/output/CommonHTML/jax.js 
At P2, significant differences were found for episiotomy rates, rates of high-grade perineal tears and labial tears. Women with PAV and CAV had more often an episiotomy $(p=0.001)$, women with CAV had higher rates of high-grade perineal tears $(p=0.031)$ and women with intact LAM showed more often labial tears (0.017).

At P3, significant differences were found for labial tears and anterior prolapse rates, with women with intact LAM showing more often labial tears ( $p=0.003$ ) and women with CAV suffering more often from an anterior prolapse $(p=0.036)$.

\section{Assessment of women's complaints Assessment regarding the time before and during pregnancy}

Before pregnancy, $87-100 \%$ of women were free from any urinary incontinence, and up to $8.5 \%$ complained about urinary incontinence from time to time. During pregnancy, however, $36-46 \%$ of women reported urinary incontinence from time to time and up to $7 \%$ even daily. The rates for stool incontinence were very low at all times, with a maximum of $4 \%$ from time to time during pregnancy. Nevertheless, $29-43 \%$ of women suffered from flatus incontinence before pregnancy and even $43-64 \%$ during pregnancy. Prolapse symptoms were rare before pregnancy (3-7\%), but present in 16-24\% of women during pregnancy.

No significant differences between the four LAM state groups were assessed regarding the complaints before and during pregnancy (Supplement 1).

\section{Assessment at 1-4 days after birth (P1)}

Significant differences in maternal complaints shortly after birth were found in relation to involuntary stool loss compared to the time before birth $(p=0.036)$ and in relation to the vaginal opening after birth $(p=0.037)$, as can be seen in Table 3 .

Women with a PAV were not affected from involuntary stool loss at all. Among the 10 affected women suffering from involuntary stool loss, only the women with a CAV $(n=3)$ were all more often affected compared to the time before birth, all other women showed an unchanged or even improved situation compared to the time before childbirth.

$75 \%$ of women in the intact LAM group did not feel a change of their vaginal opening after birth in contrast to just about half (51-57\%) of the women in the three LAM trauma groups. Only $10 \%$ of the women with intact LAM had the feeling of a wider vaginal opening in contrast to up to $28 \%$ in the CAV group.

When comparing the first few days after birth with the time during pregnancy, it seems that women complain less about urine incontinence (13-28\% vs. $36-$ $51 \%$ ), little less about flatus incontinence ( $39-56 \%$ vs. $43-64 \%)$, and little more about prolapse symptoms (7-48\% vs. 16-24\%) and stool incontinence (3$12 \%$ vs. $3-5 \%)$.

\section{Assessment at 6-10 weeks after birth (P2)}

Statistically significant results for the three different LAM state groups (intact vs PAV vs CAV) at P2 were found for involuntary gas loss compared to the time before birth $(p=0.003)$ and for pelvic floor strength $(p=0.001)$, as can be seen in Table 4.

The rates of involuntary bowel gas loss did not differ significantly between the LAM state groups at P2, but differed for the groups compared to the time before birth. However, if women complained about involuntary bowel gas loss, $82 \%$ of those with an intact LAM had an unchanged situation compared to the time before birth, whereas $46-50 \%$ of women in the LAM trauma groups reported a higher frequency of uncontrolled loss of bowel gas. Interestingly, one third of women in the PAV group even reported an improvement of bowel gas loss.

$52-57 \%$ of the women in the LAM trauma groups reported about a weaker pelvic floor at P2 compared to the time before birth, in contrast to just $25 \%$ of women with a weaker pelvic floor in the intact LAM group. No woman in the LAM trauma groups mentioned a stronger pelvic floor, in contrast to $5 \%$ of women in the intact LAM group.

When comparing P2 with P1, it seems that women complain more about urine incontinence (27-33\% vs. $13-28 \%)$, less about prolapse symptoms (12-27\% vs. $7-48 \%)$, less about flatus incontinence (24-37\% vs. $39-56 \%)$, and less about stool incontinence $(1.9-5.3 \%$ vs. $3-12 \%)$.

\section{Assessment at 6-9 months after birth (P3)}

Significant results for the different LAM state groups at P3 were found for the feeling of something squeezing downwards into the vagina ( $p=0.035)$, for the frequency of pelvic floor exercise performance $(p=0.034)$ and for satisfaction with sexual intercourse $(p=0.040)$, as can be seen in Table 5 .

$18-35 \%$ of women after vaginal birth had the feeling of something squeezing downwards into the vagina after birth. There were no significant differences regrading this rate between the three LAM state groups. However, in women who described this feeling, all of them described it being apparent more often in the intact LAM group, all of them being unchanged in the PAV group and mainly being unchanged to more often in the CAV group.

Regarding pelvic floor muscle exercise, only half of the women in the PAV group performed some training in contrast to $81-85 \%$ in the intact LAM and CAV group, respectively.

$85-91 \%$ of women had sexual intercourse after birth. $60-83 \%$ reported an unchanged situation regarding sexual satisfaction. Nevertheless, $20-29 \%$ of women in the intact LAM and PAV group reported a reduced satisfaction compared to just $5.6 \%$ in the CAV group, but $20 \%$ of women in the intact LAM group had an increased satisfaction in contrast to none in the PAV and CAV group. 
When comparing the women in the different LAM state groups at P3 with P2, it seems that women with intact LAM report less often about involuntary urine loss ( 18 vs $28 \%$ ), but women with a LAM trauma complain more often about urine incontinence ( $40-45 \%$ vs. $27-33 \%)$. Rates for stool incontinence are comparable between the groups and assessment periods. Bowel gas incontinence was less present at P3 compared to P2 (18-30\% vs. 24-37\%), as were prolapse symptoms (9-40\% vs. $12-23 \%$ ). Women at P3 performed more often pelvic floor exercise compared to P2 (50-85\% vs. $57-63 \%)$ and had sexual intercourse in $85-91 \%$ of cases in contrast to just $30-39 \%$ at $P 2$.

\section{Discussion}

Vaginal birth changes the anatomical structure of the maternal birth canal and genital tract, and it alters women`s perceptions and body function. In our study, LAM trauma does not seem to change urogynecological perceptions of women after vaginal birth tremendously within the first months, although there arise some significant differences in women with and without LAM trauma. Therefore, other maternal, fetal and obstetrical factors have to be considered for the explanation of maternal complaints besides LAM trauma.

\section{Differences in baseline characteristics within the cohort}

For our study cohort, we found significant differences in the baseline characteristics of the different LAM state groups for the birth mode, the duration of the second stage of labor, and for the rate of epidural anesthesia, episiotomies, high-grade perineal tears, labial tears and anterior prolapse, depending on the time after birth respectively. These differences are probably due to an altered biomechanics of birth in the LAM trauma groups compared to women with an intact LAM. Women with a PAV or CAV had more often a vacuum-assisted birth at P1 than those women with an intact LAM or hematoma. It remains unclear, whether the performance of the vacuum-maneuver itself might have caused the damage or if the dimensions of the fetus in relation to the maternal birth canal were more often unfavorable resulting in the need for assisted vaginal birth. Damage due to the vacuum maneuver itself could have been due to a fast performance of the maneuver with too little time for the tissue to stretch and adapt or due to an unfavorable position and rotation of the child within the birth canal. In a recent publication of our group, we could not evaluate a significant maternal, fetal or obstetrical factor during vacuum maneuver associated to the incidence of LAM avulsions, but we could not control for the just mentioned factors there (20). Hence, the relation of the fetus and the birth canal and their adaptations to each other during the birth process might be crucial. The higher rate of episiotomies at P1 and P2 and higher rates of high-grade perineal tears at P2 as well as the longer duration of the second stage of labor at P1 in women with LAM trauma probably support this explanation. An unfavorable biomechanical interaction of the fetus and the birth canal might be associated with a prolonged and more complicated birth process and might lead to more interventions. Additionally, it is known that whenever tears in the posterior compartment or episiotomies are present, less tears in the anterior compartment occur, such as labial tears. Therefore, women with intact LAM and with fewer injuries in the posterior compartment might have had higher rates of labial tears in our cohort. The same was seen at P3 for labial tears.

Women with a hematoma or complete avulsion had less often an epidural anesthesia at P1 in this study. From biomechanical simulation studies one can conclude that a relaxed pelvic floor during birth with no additional co-activation of the pelvic floor muscles reduces the stretch forces on the LAM, as can be achieved by the application of an epidural anesthesia (21). A study of Youssef et al supports this statement, as it showed that a LAM co-activation was associated with a longer second stage of labor in nulliparous women (22). Hence, an epidural might have been protective regarding pelvic floor trauma in our cohort.

Strong associations for CAV and prolapse symptoms in later life are described in the literature many years after childbirth $(13,23,24)$. We could find such an association already some months after birth in our cohort, with higher anterior prolapse rates in women with CAV.

\section{Assessment of women 's complaints regarding the time before and during pregnancy}

No significant differences between the four LAM state groups were assessed regarding the time before and during pregnancy, resembling a homogeneous cohort of women in our study. The incontinence rates found in our cohort are in accordance with the rates in the literature (25-27). Most women had no incontinence or prolapse symptoms before pregnancy, but reported about any of them in up to $4-64 \%$ during pregnancy. These numbers underline that pregnancy itself with its mechanical and hormonal changes alters the voiding and defecation function, and it influences the anatomical organ structures.

\section{Assessment of women's complaints 1-4 days after birth (P1)}

Only women with a CAV were all more often affected regarding involuntary stool loss compared to the time before birth. The women in the three other groups reported an unchanged or even improved status. The higher number of affected women in the CAV group cannot be explained by the presence of a high-grade perineal tear, as the rates did not differ significantly between the groups. An explanation could be an altered anal sphincter and levator ani muscle function due to a possible nerve damage or pelvic floor muscle overdistension within the first days after birth rather than a structural muscle damage due to a more complicated birth in that CAV group as mentioned above. Weidner et al found a neuropathic injury of the levator ani muscle in $24-29 \%$ of women at 6 weeks and 6 months after childbirth respectively (28).

Only $10 \%$ of women in the intact LAM group had the feeling of a wider vaginal opening, whereas $75 \%$ did not feel any change after birth. In contrast, up to $28 \%$ in the CAV group had the feeling of a wider vaginal opening and $51-57 \%$ of women in the three LAM trauma groups feeling unchanged. A wider vaginal opening is caused either by a structural widening, for example by an avulsion of the LAM, or by a functional widening by overdistension of the genital hiatus and the vagina or by neuropathic injury (28). Besides the structural damage of the LAM in the CAV group, the functional widening by a longer second stage of labor in the LAM trauma groups could explain the higher number of women with the feeling of a wider vagina in the trauma groups. In addition, tissue characteristics and distension capabilities of the individual woman might substantially contribute to the altered body anatomy and perception.

Loading [MathJax]/jax/output/CommonHTML/jax.js veeks after birth (P2) 
The rates of involuntary bowel gas loss did not differ significantly between the LAM state groups at P2 compared to the time before birth, although the rate of high-grade perineal tears was significantly higher in the CAV group with $6.7 \%$ vs. $0.6 \%$ in the intact LAM group. However, if women complained about involuntary bowel gas loss, the situation remained stable in about $82 \%$ of women in the intact LAM group, whereas $46-50 \%$ of women in the LAM trauma groups reported a higher frequency of uncontrolled bowel gas loss. Again, besides the structural damage of the anal sphincter, a functional impairment by for example nerve impairment might be crucial, and functional damage is more likely in complicated births. Interestingly, one third of women in the PAV group even reported an improvement of bowel gas loss. We do not have any explanation for this phenomenon.

Women in the LAM trauma groups had more often a weaker pelvic floor at P2 compared to the time before birth than women in the intact LAM group (52-57\% vs. $25 \%$ ). Besides, no woman in the LAM trauma groups mentioned a stronger pelvic floor, in contrast to $5 \%$ of women in the intact LAM group. As a defect of the pelvic floor muscle in form of a PAV or CAV negatively affects the performance of the LAM, this association seems comprehensible and is described in the literature as well (24).

\section{Assessment of women's complaints 6-9 months after birth (P3)}

$18-35 \%$ of women after vaginal birth had the feeling of something squeezing downwards into the vagina after birth. There were no significant differences regrading this rate between the three LAM state groups. However, in women who described this feeling, all of them described it being apparent more often in the intact LAM group, whereas all women in the PAV group and most women in the CAV group described the situation as unchanged. This is interesting, as we would have expected such a complaint more frequently in the CAV group with the higher rate of anterior prolapse, especially as this phenomenon is reported in the literature $(23,29)$. Hence, a functional problem of the pelvic floor with "just" overdistension of the LAM instead of avulsion could explain this phenomenon in the intact LAM group. Unfortunately, overdistension of the genital hiatus was not evaluated with this study, so we cannot proof this idea. Besides, the number of women in the groups regarding this topic was very small, and conclusions need to be drawn with great caution.

Although women in the CAV group trained their pelvic floor more frequently, they suffered more often from an anterior prolapse than women in the PAV or intact LAM group. Hence, pelvic floor training cannot completely compensate the anatomical defect set by a CAV, but maybe can improve the extent and rate of prolapse in this group.

85-91\% of women had sexual intercourse 6-9 months after birth, which is comparable with other studies showing that $89 \%$ of women resume sexual activity within 6 months of giving birth (30). Of those women, $60-83 \%$ reported an unchanged situation regarding sexual satisfaction. Nevertheless, $20-29 \%$ of women in the intact LAM and PAV group reported a reduced satisfaction compared to just $5.6 \%$ in the CAV group. $20 \%$ of women in the intact LAM group even had an increased satisfaction in contrast to none in the PAV and CAV group respectively. In the literature, a comparable reduction of sexual function and satisfaction is reported after vaginal birth in comparison to the pre-pregnancy period, with sexual dysfunction rates of up to $64 \%$ at 6 months after birth (31). Other studies report that sexual function after birth is not altered by pelvic floor muscle strength or mode of delivery, but by the presence of high-grade perineal tears $(30,32,33)$. The association of sexual function and satisfaction to the presence of a LAM avulsion remains controversial $(29,34)$.

Complaints about urinary incontinence changed over the course of pregnancy and the postpartum period. 36-51\% of women declared urinary incontinence during pregnancy, $13-28 \%$ at $\mathrm{P} 1,27-33 \%$ at $\mathrm{P} 2$ and $18 \%-45 \%$ at $\mathrm{P} 3$, with $18 \%$ in the intact LAM group and $40-45 \%$ in the LAM trauma groups. The improvement might be due to a natural recovery of the nerve structures of the pelvic floor and bladder, intrinsic improvement of pelvic floor muscle function and effects of pelvic floor muscle training. In contrast to the higher rate of urinary incontinence in women with LAM trauma in our study, other studies found no differences in stress urinary incontinence after vaginal birth in women with or without LAM trauma $(35,36)$. A similar trend and course can be seen for flatus incontinence in our study. It was the highest during pregnancy (43-64\%), with a decrease over time from $39-56 \%$ at P1 to $24-37 \%$ at P2 and to $18-$ $30 \%$ at P3. Prolapse symptoms were found in $16-24 \%$ during pregnancy, in $7-48 \%$ at P1, in $12-27 \%$ at P2 and in $9-40 \%$ at P3, with women in the LAM trauma groups being more often affected, especially women with CAV. However, women with intact LAM were also affected. Therefore, prolapse symptoms are not solely associated to structural LAM defects, but also to functional impairments, as for example the lower capability to recruit and control pelvic floor muscles. Stool incontinence was more or less stable, with $3-5 \%$ during pregnancy, $3-12 \%$ at P1, $1.9-5.3 \%$ at P2 and $0-5 \%$ at P3.

A strength of our study is definitely the longitudinal, prospective design with antenatal inclusion of the participants into the study, a small dropout rate regarding the LAM assessment 6-10 weeks after birth, and the validated assessment methods. Nevertheless, a limitation is the small number of women with LAM trauma at all assessment periods and the small cohort of women with intact LAM at P3 for comparison. For a more precise evaluation of the possible causes of women's complaints it would be necessary to not only check for structural LAM trauma, but even for functional trauma. The dimensions of the genital hiatus should be examined to detect possible overdistension, and the pelvic floor muscles and the innervating nerves need to be checked for impaired recruitment and function. Besides, the surrounding connective and soft tissue of the pelvis and the birth canal need to be evaluated. Furthermore, it would be worthwhile to find a way to get more insight into the adaptation processes of fetus and birth canal. In a first step, simulation models could help to calculate the maternal bony and soft tissues, the different size relations of the fetus and birth canal, the adaptation processes of the these structures to the passing fetus, the adaptations of the fetus to the birth canal including its rotation, head flexion and head molding, and the different labor durations for the necessary adaptations.

\section{Conclusions}

Vaginal birth changes the anatomical structure of the maternal birth canal and genital tract, and it alters women sbodyperceptions and function. Inourstudy, LAMtraumadseem $\rightarrow$ chan $\geq$ theeffectsofavag $\in$ albirthtremendouslywith $\in$ thefirstmonths, a s impairment.

Loading [MathJax]/jax/output/CommonHTML/jax.js 


\section{List Of Abbreviations}

CAV complete avulsion

LAM levator ani muscle

P period

PAV partial avulsion

TLUS translabial ultrasound

4D 4-dimensional

\section{Declarations}

\section{Ethics approval}

The study was performed according to the Declaration of Helsinki and to national guidelines. It was approved by the Local Ethical Board of the District ("Kantonale Ethikkommission, Kanton Zürich, Switzerland") under the registration BASEC-No. 2016-00908. Additionally, all study participants gave their written informed consent for the study.

\section{Consent for publication}

Not applicable.

\section{Availability of data and materials}

The datasets used and/or analysed during the current study are available from the corresponding author on reasonable request.

\section{Competing interests}

The authors declare that they have no competing interests.

\section{Funding}

The study was supported by GE Healthcare, Zipf, Austria by providing the ultrasound device (Voluson S10) and probes for the ultrasound examinations during the whole study period.

The Heartbay Foundation (Vaduz, Liechtenstein) supported the project financially.

\section{Authors`contribution}

N Kimmich: Study conception, ultrasound performance, data acquisition and management, statistical analysis, manuscript writing

J Birri: Data acquisition and management, manuscript editing

A Richter: Data acquisition, manuscript editing

R Zimmermann: Study conception, manuscript editing

M Kreft: Study conception, ultrasound performance, data acquisition and management, manuscript editing

\section{Acknowledgments}

There are no acknowledgements

\section{References}

1. van Delft K, Thakar R, Sultan AH, Schwertner-Tiepelmann N, Kluivers K. Levator ani muscle avulsion during childbirth: a risk prediction model. BJOG. 2014;121(9):1155-63; discussion 63.

2. Dietz HP, Lanzarone V. Levator trauma after vaginal delivery. Obstet Gynecol. 2005;106(4):707-12.

3. Albrich SB, Laterza RM, Skala C, Salvatore S, Koelbl H, Naumann G. Impact of mode of delivery on levator morphology: a prospective observational study with three-dimensional ultrasound early in the postpartum period. BJOG. 2012;119(1):51-60.

4. Shek KL, Dietz HP. Intrapartum risk factors for levator trauma. BJOG. 2010;117(12):1485-92.

5. Valsky DV, Lipschuetz M, Bord A, Eldar I, Messing B, Hochner-Celnikier D, et al. Fetal head circumference and length of second stage of labor are risk factors for levator ani muscle injury, diagnosed by 3-dimensional transperineal ultrasound in primiparous women. Am J Obstet Gynecol. 2009;201(1):91 
6. Kimmich N, Birri J, Zimmermann R, Kreft M. Prediction of levator ani muscle avulsion by genital tears after vaginal birth-a prospective observational cohort study. Int Urogynecol J. 2020.

7. Kearney R, Fitzpatrick M, Brennan S, Behan M, Miller J, Keane D, et al. Levator ani injury in primiparous women with forceps delivery for fetal distress, forceps for second stage arrest, and spontaneous delivery. Int J Gynaecol Obstet. 2010;111(1):19-22.

8. Radestad I, Olsson A, Nissen E, Rubertsson C. Tears in the vagina, perineum, sphincter ani, and rectum and first sexual intercourse after childbirth: a nationwide follow-up. Birth. 2008;35(2):98-106.

9. Skinner EM, Dietz HP. Psychological and somatic sequelae of traumatic vaginal delivery: A literature review. Aust N Z J Obstet Gynaecol. 2015;55(4):30914.

10. Dietz HP, Schierlitz L. Pelvic floor trauma in childbirth - myth or reality? Aust N Z J Obstet Gynaecol. 2005;45(1):3-11.

11. Dannecker C, Lienemann A, Fischer T, Anthuber $C$. Influence of spontaneous and instrumental vaginal delivery on objective measures of pelvic organ support: assessment with the pelvic organ prolapse quantification (POPQ) technique and functional cine magnetic resonance imaging. Eur $\mathrm{J}$ Obstet Gynecol Reprod Biol. 2004;115(1):32-8.

12. Abdool Z, Shek KL, Dietz HP. The effect of levator avulsion on hiatal dimension and function. Am J Obstet Gynecol. 2009;201(1):89 e1-5.

13. Dietz HP, Franco AV, Shek KL, Kirby A. Avulsion injury and levator hiatal ballooning: two independent risk factors for prolapse? An observational study. Acta Obstet Gynecol Scand. 2012;91(2):211-4.

14. Dietz HP, Steensma AB. The prevalence of major abnormalities of the levator ani in urogynaecological patients. BJOG. 2006;113(2):225-30.

15. Dietz HP. Ultrasound imaging of the pelvic floor. Part II: three-dimensional or volume imaging. Ultrasound Obstet Gynecol. 2004;23(6):615-25.

16. Dietz HP, Moegni F, Shek KL. Diagnosis of levator avulsion injury: a comparison of three methods. Ultrasound Obstet Gynecol. 2012;40(6):693-8.

17. Dietz HP, Bernardo MJ, Kirby A, Shek KL. Minimal criteria for the diagnosis of avulsion of the puborectalis muscle by tomographic ultrasound. Int Urogynecol J. 2011;22(6):699-704.

18. Dietz HP. Ultrasound imaging of maternal birth trauma. Int Urogynecol J. 2021.

19. Kimmich N, Burkhardt T, Kreft M, Zimmermann R. Reducing birth trauma by the implementation of novel monitoring and documentation tools. Acta Obstet Gynecol Scand. 2019;98(10):1223-6.

20. Kimmich N, Birri J, Zimmermann R, Kreft M. Association between levator ani avulsions and technique of vacuum extraction - a prospective observational study. Swiss Med Wkly (accepted for publication). 2020.

21. Parente MP, Natal Jorge RM, Mascarenhas T, Silva-Filho AL. The influence of pelvic muscle activation during vaginal delivery. Obstet Gynecol. 2010;115(4):804-8.

22. Youssef A, Montaguti E, Dodaro MG, Kamel R, Rizzo N, Pilu G. Levator ani muscle coactivation at term is associated with longer second stage of labor in nulliparous women. Ultrasound Obstet Gynecol. 2019;53(5):686-92.

23. Handa VL, Blomquist JL, Roem J, Munoz A, Dietz HP. Pelvic Floor Disorders After Obstetric Avulsion of the Levator Ani Muscle. Female Pelvic Med Reconstr Surg. 2019;25(1):3-7.

24. Handa VL, Roem J, Blomquist JL, Dietz HP, Munoz A. Pelvic organ prolapse as a function of levator ani avulsion, hiatus size, and strength. Am J Obstet Gynecol. 2019;221(1):41 e1- e7.

25. Thom DH, Rortveit G. Prevalence of postpartum urinary incontinence: a systematic review. Acta Obstet Gynecol Scand. 2010;89(12):1511-22.

26. Press JZ, Klein MC, Kaczorowski J, Liston RM, von Dadelszen P. Does cesarean section reduce postpartum urinary incontinence? A systematic review. Birth. 2007;34(3):228-37.

27. Moossdorff-Steinhauser HFA, Berghmans BCM, Spaanderman MEA, Bols EMJ. Prevalence, incidence and bothersomeness of urinary incontinence in pregnancy: a systematic review and meta-analysis. Int Urogynecol J. 2021.

28. Weidner AC, Jamison MG, Branham V, South MM, Borawski KM, Romero AA. Neuropathic injury to the levator ani occurs in 1 in 4 primiparous women. Am J Obstet Gynecol. 2006;195(6):1851-6.

29. Thibault-Gagnon S, Yusuf S, Langer S, Wong V, Shek KL, Martin A, et al. Do women notice the impact of childbirth-related levator trauma on pelvic floor and sexual function? Results of an observational ultrasound study. Int Urogynecol J. 2014;25(10):1389-98.

30. Gutzeit O, Levy G, Lowenstein L. Postpartum Female Sexual Function: Risk Factors for Postpartum Sexual Dysfunction. Sex Med. 2020;8(1):8-13.

31. Signorello LB, Harlow BL, Chekos AK, Repke JT. Postpartum sexual functioning and its relationship to perineal trauma: a retrospective cohort study of primiparous women. Am J Obstet Gynecol. 2001;184(5):881-8; discussion 8-90.

32. Baytur YB, Deveci A, Uyar Y, Ozcakir HT, Kizilkaya S, Caglar H. Mode of delivery and pelvic floor muscle strength and sexual function after childbirth. Int $\mathrm{J}$ Gynaecol Obstet. 2005;88(3):276-80.

33. De Souza A, Dwyer PL, Charity M, Thomas E, Ferreira CH, Schierlitz L. The effects of mode delivery on postpartum sexual function: a prospective study. BJOG. 2015;122(10):1410-8.

34. Garcia-Mejido JA, Idoia-Valero I, Aguilar-Galvez IM, Borrero Gonzalez C, Fernandez-Palacin A, Sainz JA. Association between sexual dysfunction and avulsion of the levator ani muscle after instrumental vaginal delivery. Acta Obstet Gynecol Scand. 2020.

35. Garcia Mejido JA, Valdivieso Mejias P, Fernandez Palacin A, Bonomi Barby MJ, De la Fuente Vaquero P, Sainz Bueno JA. Evaluation of isolated urinary stress incontinence according to the type of levator ani muscle lesion using 3/4D transperineal ultrasound 36 months post-partum. Int Urogynecol J. 2017;28(7):1019-26.

Loading [MathJax]/jax/output/CommonHTML/jax.js 
36. Heilbrun ME, Nygaard IE, Lockhart ME, Richter HE, Brown MB, Kenton KS, et al. Correlation between levator ani muscle injuries on magnetic resonance imaging and fecal incontinence, pelvic organ prolapse, and urinary incontinence in primiparous women. Am J Obstet Gynecol. 2010;202(5):488 e1-6.

\section{Tables}


Table 1

Questionnaire for assessing the urogynecological conditions of the study population before and during pregnancy and for the time after birth

\section{Questions regarding the time before and during pregnancy}

1.) I lost urine involuntary/ against my will

2.) I lost stool involuntary/ against my will

3.) I lost gas involuntary/ against my will

4.) I had burning/painful sensations during defecation

5.) I had burning/painful sensations during sexual intercourse

6.) I had a feeling of discomfort/ foreign body in the vagina

7.) I had the feeling of something squeezing downwards into the vagina

Questions regarding the time after birth

8.) I loose urine involuntary/against my will

9.) Compared to the time before childbirth I lose urine involuntary/against my will

10.) I lose stool involuntary/ against my will

11.) Compared to the time before childbirth I lose stool involuntary/against my will

12.) I lose gas involuntary/ against my will

13.) Compared to the time before childbirth I lose bowel gas involuntary/ against my will

14.) I have a feeling of discomfort/foreign body in the vagina

15.) Compared to the time before childbirth I have a feeling of discomfort/ foreign body in the vagina

16.) I have the feeling of something squeezing downwards into the vagina

17.) Compared to the time before childbirth I have the feeling of something squeezing downwards into the vagina

18.) Compared to the time before childbirth I have the feeling, that my vaginal opening is

19.) Compared to the time before childbirth I have the feeling, that my pelvic floor is

20.) I do pelvic floor exercise

21.) Compared to the time before delivery, I do pelvic floor exercise

22.) I already had sexual intercourse after delivery

23.) Compared to the time before delivery, my vagina is

24.) Sexual intercourse is painful

25.) Compared to the time before delivery, sexual intercourse is painful

\section{Possible answers}

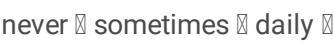

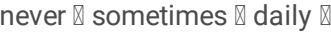

never $₫$ sometimes $₫$ daily $\llbracket$

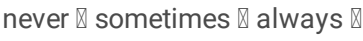

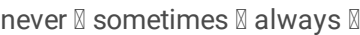

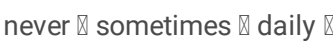

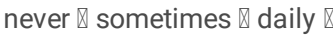

Possible answers

Yes $₫$ No $₫$

\begin{tabular}{lllllllll}
$\begin{array}{l}\text { less } \\
\text { often }\end{array}$ & 1 & 2 & 3 & 4 & 5 & 6 & 7 & $\begin{array}{r}\text { more } \\
\text { often }\end{array}$ \\
\hline
\end{tabular}

Yes $₫$ No $\otimes$

\begin{tabular}{|lllllllll|}
\hline $\begin{array}{l}\text { less } \\
\text { often }\end{array}$ & 1 & 2 & 3 & 4 & 5 & 6 & 7 & $\begin{array}{c}\text { more } \\
\text { often }\end{array}$ \\
\hline
\end{tabular}

Yes $₫$ No $₫$

\begin{tabular}{lllllllll}
$\begin{array}{l}\text { less } \\
\text { often }\end{array}$ & 1 & 2 & 3 & 4 & 5 & 6 & 7 & $\begin{array}{l}\text { more } \\
\text { often }\end{array}$ \\
\hline
\end{tabular}

Yes $\otimes$ No $\bigotimes$

\begin{tabular}{lllllllll}
$\begin{array}{l}\text { less } \\
\text { often }\end{array}$ & 1 & 2 & 3 & 4 & 5 & 6 & 7 & $\begin{array}{r}\text { more } \\
\text { often }\end{array}$ \\
\hline
\end{tabular}

Yes $₫$ No $₫$

\begin{tabular}{|lllllllll|}
\hline $\begin{array}{l}\text { less } \\
\text { often }\end{array}$ & 1 & 2 & 3 & 4 & 5 & 6 & 7 & $\begin{array}{c}\text { more } \\
\text { often }\end{array}$ \\
\hline
\end{tabular}

\begin{tabular}{|lllllllll|}
\hline $\begin{array}{l}\text { tighter/ } \\
\text { closer }\end{array}$ & 1 & 2 & 3 & 4 & 5 & 6 & 7 & wider \\
\hline
\end{tabular}

\begin{tabular}{|lllllllll|}
\hline weaker & 1 & 2 & 3 & 4 & 5 & 6 & 7 & stronger
\end{tabular}

Yes $\triangle$ No $\bigotimes$

\begin{tabular}{|lllllllll|}
\hline $\begin{array}{l}\text { less } \\
\text { frequently }\end{array}$ & 1 & 2 & 3 & 4 & 5 & 6 & 7 & $\begin{array}{l}\text { more } \\
\text { frequently }\end{array}$ \\
\hline
\end{tabular}

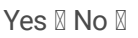

$\begin{array}{lllllllll}\text { drier } & 1 & 2 & 3 & 4 & 5 & 6 & 7 & \text { wetter }\end{array}$

Yes $₫$ No $\llbracket$

\begin{tabular}{|lllllllll}
\hline $\begin{array}{l}\text { less } \\
\text { frequently }\end{array}$ & 1 & 2 & 3 & 4 & 5 & 6 & 7 & $\begin{array}{l}\text { more } \\
\text { frequently }\end{array}$ \\
\hline
\end{tabular}


26.) Compared to the time before delivery, my orgasm capability is

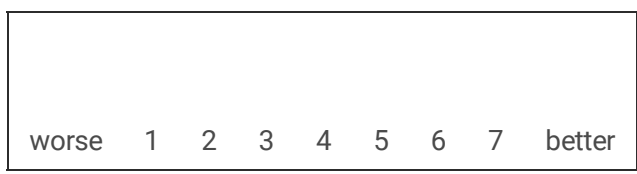

27.) Compared to the time before delivery, my sensation in the vagina during sexual intercourse is

$\begin{array}{lllllllll}\text { reduced } & 1 & 2 & 3 & 4 & 5 & 6 & 7 & \text { increased }\end{array}$

28.) Compared to the time before delivery, my satisfaction with sexual intercourse is

$\begin{array}{lllllllll}\text { reduced } & 1 & 2 & 3 & 4 & 5 & 6 & 7 & \text { increased }\end{array}$

The answer " 4 " represented an unchanged situation after birth compared to the time before pregnancy 
Table 2

Baseline demographic and obstetric data of the study cohort according their allocation to their LAM trauma state and to the time of evaluation at P1-P3

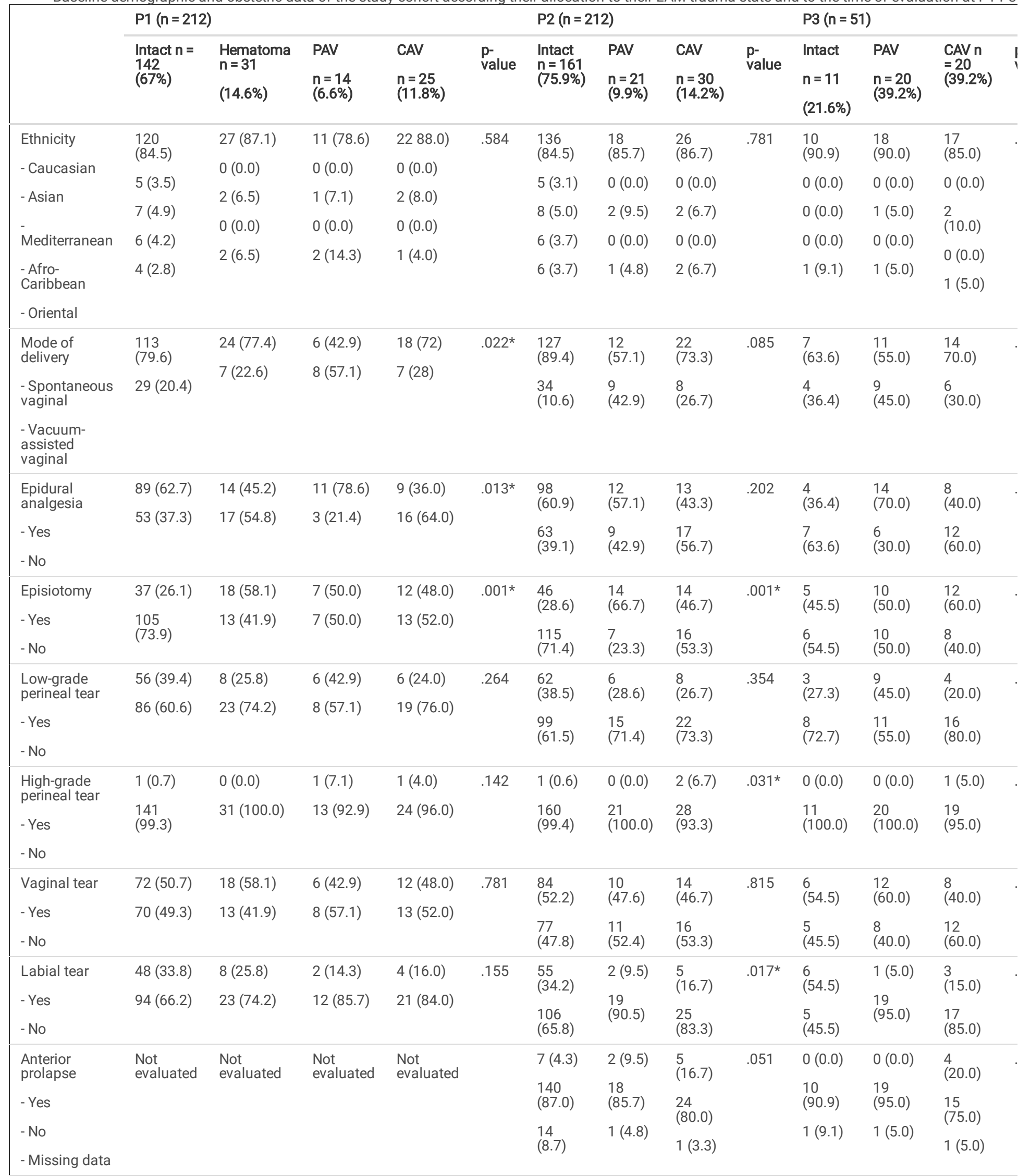




\begin{tabular}{|c|c|c|c|c|c|c|c|c|c|c|c|c|}
\hline & \multicolumn{5}{|c|}{$P 1(n=212)$} & \multicolumn{4}{|c|}{$P 2(n=212)$} & \multicolumn{3}{|c|}{ P3 $(n=51)$} \\
\hline & $\begin{array}{l}\text { Intact } n= \\
142 \\
(67 \%)\end{array}$ & $\begin{array}{l}\text { Hematoma } \\
n=31 \\
(14.6 \%)\end{array}$ & $\begin{array}{l}\text { PAV } \\
n=14 \\
(6.6 \%)\end{array}$ & $\begin{array}{l}\text { CAV } \\
n=25 \\
(11.8 \%)\end{array}$ & $\begin{array}{l}\text { p- } \\
\text { value }\end{array}$ & $\begin{array}{l}\text { Intact } \\
n=161 \\
(75.9 \%)\end{array}$ & $\begin{array}{l}\text { PAV } \\
n=21 \\
(9.9 \%)\end{array}$ & $\begin{array}{l}\text { CAV } \\
n=30 \\
(14.2 \%)\end{array}$ & $\begin{array}{l}\mathrm{p}- \\
\text { value }\end{array}$ & $\begin{array}{l}\text { Intact } \\
n=11 \\
(21.6 \%)\end{array}$ & $\begin{array}{l}\text { PAV } \\
n=20 \\
(39.2 \%)\end{array}$ & $\begin{array}{l}\text { CAV n } \\
=20 \\
(39.2 \%)\end{array}$ \\
\hline $\begin{array}{l}\text { Posterior } \\
\text { prolapse } \\
\text { - Yes }\end{array}$ & $\begin{array}{l}\text { Not } \\
\text { evaluated }\end{array}$ & $\begin{array}{l}\text { Not } \\
\text { evaluated }\end{array}$ & $\begin{array}{l}\text { Not } \\
\text { evaluated }\end{array}$ & $\begin{array}{l}\text { Not } \\
\text { evaluated }\end{array}$ & & $\begin{array}{l}1(0.6) \\
145( \\
90.1)\end{array}$ & $\begin{array}{l}0(0.0) \\
20 \\
(95.2)\end{array}$ & $\begin{array}{l}0(0.0) \\
29 \\
(96.7)\end{array}$ & .845 & $\begin{array}{l}0(0.0) \\
9 \\
(81.8)\end{array}$ & $\begin{array}{l}1(5.0) \\
18 \\
(90.0)\end{array}$ & $\begin{array}{l}0(0.0) \\
19 \\
(95.0)\end{array}$ \\
\hline $\begin{array}{l}\text { - No } \\
\text { - Missing data }\end{array}$ & & & & & & $\begin{array}{l}15 \\
(9.3)\end{array}$ & $1(4.8)$ & $1(3.3)$ & & $\begin{array}{l}2 \\
(18.2)\end{array}$ & $1(5.0)$ & $1(5.0)$ \\
\hline $\begin{array}{l}\text { Central } \\
\text { prolapse }\end{array}$ & $\begin{array}{l}\text { Not } \\
\text { evaluated }\end{array}$ & Not & Not & Not & & $2(1.2)$ & $0(0.0)$ & $0(0.0)$ & .708 & $0(0.0)$ & $0(0.0)$ & 2 \\
\hline - Yes & & & & & & $\begin{array}{l}144 \\
(89.4)\end{array}$ & $\begin{array}{l}21 \\
(100.0)\end{array}$ & $\begin{array}{l}29 \\
(96.7)\end{array}$ & & $\begin{array}{l}9 \\
(81.8)\end{array}$ & $\begin{array}{l}19 \\
(95.0)\end{array}$ & 17 \\
\hline $\begin{array}{l}\text { - No } \\
\text { - Missing data }\end{array}$ & & & & & & $\begin{array}{l}15 \\
(9.3)\end{array}$ & $0(0.0)$ & $1(3.3)$ & & $\begin{array}{l}2 \\
(18.2)\end{array}$ & $1(5.0)$ & $1(5.0)$ \\
\hline $\mathrm{BMI}$ in $\mathrm{kg} / \mathrm{m} 2$ & $23.0 \pm 4.0$ & $22.4 \pm 3.8$ & $21.7 \pm 3.6$ & $21.6 \pm 2.5$ & .329 & $\begin{array}{l}22.9 \pm \\
3.9\end{array}$ & $\begin{array}{l}20.9 \pm \\
3.0\end{array}$ & $\begin{array}{l}22.4 \pm \\
3.5\end{array}$ & .163 & $\begin{array}{l}21.3 \pm \\
3.1\end{array}$ & $\begin{array}{l}23.3 \pm \\
4.3\end{array}$ & $\begin{array}{l}21.0 \pm \\
2.2\end{array}$ \\
\hline Age in years & $33.0 \pm 3.9$ & $33.3 \pm 3.9$ & $34.2 \pm 4.9$ & $33.6 \pm 3.9$ & .661 & $\begin{array}{l}32.9 \pm \\
3.9\end{array}$ & $\begin{array}{l}33.5 \pm \\
4.6\end{array}$ & $\begin{array}{l}34.5 \pm \\
3.7\end{array}$ & .142 & $\begin{array}{l}32.1 \pm \\
4.5\end{array}$ & $\begin{array}{l}34.3 \pm \\
4.3\end{array}$ & $\begin{array}{l}33.8 \pm \\
3.5\end{array}$ \\
\hline GA in days & $279 \pm 8.2$ & $278 \pm 8.9$ & $279 \pm 7.5$ & $279 \pm 7.5$ & .943 & $\begin{array}{l}279 \pm \\
8.2\end{array}$ & $\begin{array}{l}277 \pm \\
8.4\end{array}$ & $\begin{array}{l}279 \pm \\
7.5\end{array}$ & .434 & $\begin{array}{l}281 \pm \\
5.2\end{array}$ & $\begin{array}{l}280 \pm \\
7.1\end{array}$ & $\begin{array}{l}278 \pm \\
8.1\end{array}$ \\
\hline $\begin{array}{l}\text { Duration of } \\
\text { the second } \\
\text { stage of labor } \\
\text { in min }\end{array}$ & $106 \pm 61$ & $134 \pm 61$ & $144 \pm 59$ & $128 \pm 65$ & $.018^{\star}$ & $\begin{array}{l}109 \pm \\
62\end{array}$ & $\begin{array}{l}133 \pm \\
62\end{array}$ & $\begin{array}{l}132 \pm \\
63\end{array}$ & .072 & $\begin{array}{l}127 \pm \\
61\end{array}$ & $\begin{array}{l}150 \pm \\
66\end{array}$ & $\begin{array}{l}132 \pm \\
58\end{array}$ \\
\hline $\begin{array}{l}\text { Pushing } \\
\text { duration of } \\
\text { the second } \\
\text { stage of labor } \\
\text { in min }\end{array}$ & $54 \pm 40$ & $65 \pm 40$ & $81 \pm 37$ & $64 \pm 42$ & .071 & $56 \pm 40$ & $67 \pm 40$ & $66 \pm 40$ & .241 & $67 \pm 45$ & $76 \pm 44$ & $65 \pm 38$ \\
\hline $\begin{array}{l}\text { Neonatal } \\
\text { weight }\end{array}$ & $\begin{array}{l}3332 \pm \\
397\end{array}$ & $3338 \pm 520$ & $\begin{array}{l}3382 \pm \\
347\end{array}$ & $\begin{array}{l}3458 \pm \\
342\end{array}$ & .545 & $\begin{array}{l}3348 \pm \\
412\end{array}$ & $\begin{array}{l}3311 \pm \\
448\end{array}$ & $\begin{array}{l}3397 \pm \\
361\end{array}$ & .746 & $\begin{array}{l}3546 \pm \\
440\end{array}$ & $\begin{array}{l}3382 \pm \\
416\end{array}$ & $\begin{array}{l}3448 \pm \\
336\end{array}$ \\
\hline $\begin{array}{l}\text { Neonatal } \\
\text { head } \\
\text { circumference }\end{array}$ & $34.8 \pm 1.4$ & $34.9 \pm 1.4$ & $35.1 \pm 1.5$ & $35.2 \pm 1.1$ & .457 & $\begin{array}{l}34.8 \pm \\
1.3\end{array}$ & $\begin{array}{l}35.1 \pm \\
1.4\end{array}$ & $\begin{array}{l}34.9 \pm \\
1.3\end{array}$ & .617 & $\begin{array}{l}35.0 \pm \\
1.4\end{array}$ & $\begin{array}{l}35.2 \pm \\
1.5\end{array}$ & $\begin{array}{l}35.2 \pm \\
1.2\end{array}$ \\
\hline
\end{tabular}


Pelvic floor symptoms between the four different levator ani muscle state groups $1-4$ days after birth (P1)

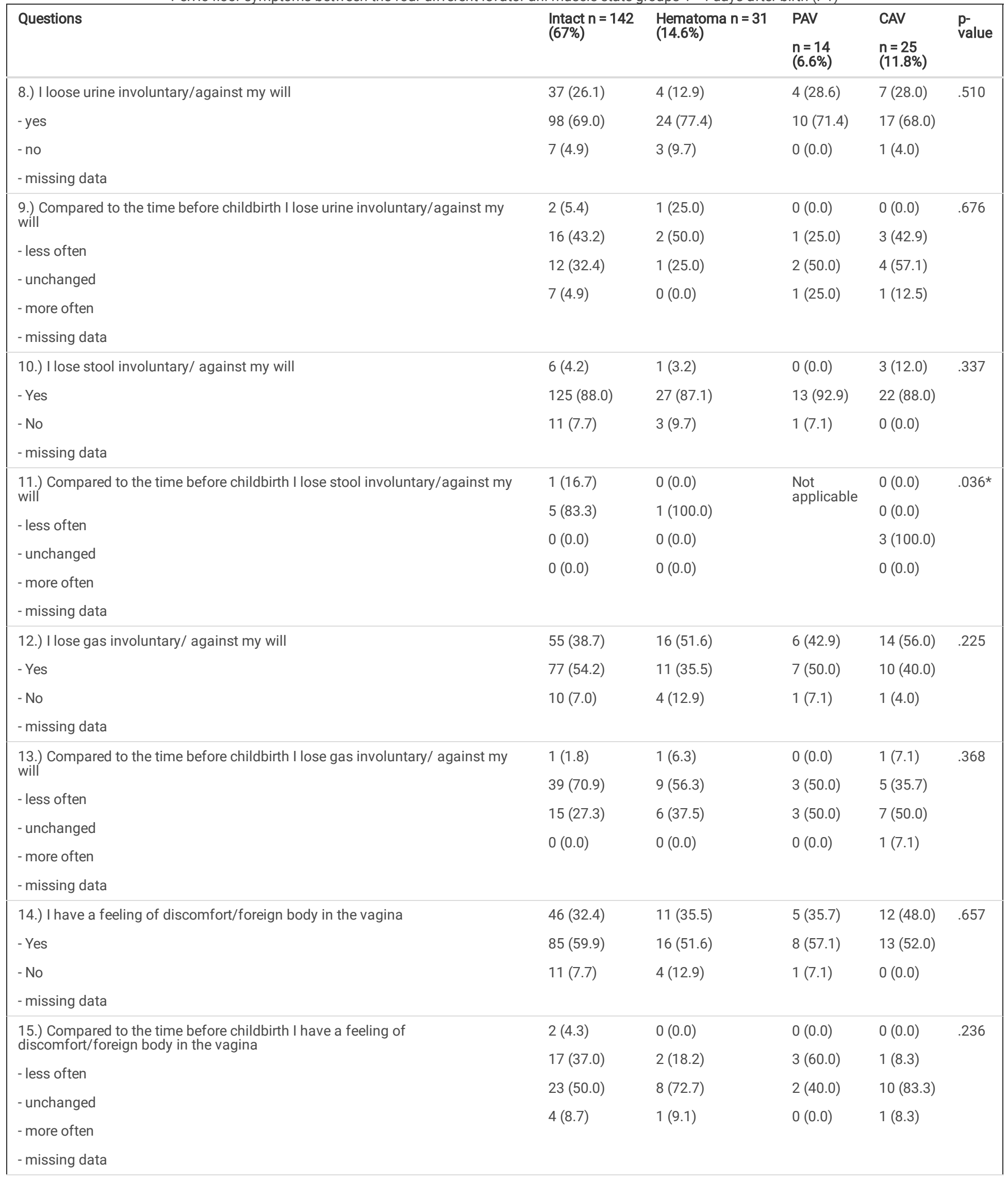




\begin{tabular}{|c|c|c|c|c|c|}
\hline Questions & $\begin{array}{l}\text { Intact } n=142 \\
(67 \%)\end{array}$ & $\begin{array}{l}\text { Hematoma } n=31 \\
(14.6 \%)\end{array}$ & $\begin{array}{l}\text { PAV } \\
n=14 \\
(6.6 \%)\end{array}$ & $\begin{array}{l}\text { CAV } \\
n=25 \\
(11.8 \%)\end{array}$ & $\begin{array}{l}\mathrm{p}- \\
\text { value }\end{array}$ \\
\hline 16.) I have the feeling of something squeezing downwards into the vagina & $24(16.9)$ & $2(6.5)$ & $2(14.3)$ & $6(24.0)$ & \multirow[t]{3}{*}{.396} \\
\hline -Yes & $109(76.8)$ & $26(83.9)$ & $12(71.4)$ & $19(76.0)$ & \\
\hline- No & $9(6.3)$ & $3(9.7)$ & $0(0.0)$ & $0(0.0)$ & \\
\hline \multicolumn{6}{|l|}{ - missing data } \\
\hline \multirow{2}{*}{$\begin{array}{l}\text { 17.) Compared to the time before childbirth I have the feeling of something } \\
\text { squeezing downwards into the vagina }\end{array}$} & $3(12.5)$ & $0(0.0)$ & $0(0.0)$ & $0(0.0)$ & \multirow[t]{5}{*}{.827} \\
\hline & $12(50.0)$ & $1(50.0)$ & $1(50.0)$ & $2(33.3)$ & \\
\hline \multirow{3}{*}{$\begin{array}{l}\text { - less often } \\
\text { - unchanged } \\
\text { - more often } \\
\text { - missing data }\end{array}$} & $8(33.3)$ & $1(50.0)$ & $1(50.0)$ & $4(66.7)$ & \\
\hline & $1(4.2)$ & $0(0.0)$ & $0(0.0)$ & $0(0.0)$ & \\
\hline & & & & & \\
\hline \multirow{2}{*}{$\begin{array}{l}\text { 18.) Compared to the time before childbirth I have the feeling, that my vaginal } \\
\text { opening is }\end{array}$} & $7(4.9)$ & $3(9.7)$ & $3(21.4)$ & $3(12.0)$ & \multirow[t]{5}{*}{$.037 *$} \\
\hline & $107(75.4)$ & $16(51.6)$ & $8(57.1)$ & $14(56.0)$ & \\
\hline 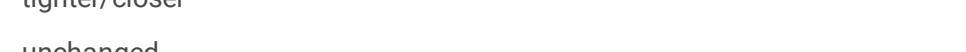 & $15(10.6)$ & $6(19.4)$ & $2(14.3)$ & $7(28.0)$ & \\
\hline & \multirow[t]{2}{*}{$13(9.2)$} & \multirow[t]{2}{*}{$6(19.4)$} & \multirow[t]{2}{*}{$1(7.1)$} & \multirow[t]{2}{*}{$1(4.0)$} & \\
\hline - missing data & & & & & \\
\hline \multirow{2}{*}{$\begin{array}{l}\text { 19.) Compared to the time before childbirth I have the feeling, that my pelvic } \\
\text { floor is }\end{array}$} & 47 (33.1) & $14(45.2)$ & $5(35.7)$ & $17(68.0)$ & \multirow[t]{5}{*}{.055} \\
\hline & 78 (54.9) & 12 (38.7) & $8(57.1)$ & $8(32.0)$ & \\
\hline wedkel & $6(4.2)$ & $0(0.0)$ & $0(0.0)$ & $0(0.0)$ & \\
\hline - stronger & \multirow[t]{2}{*}{$11(7.7)$} & \multirow[t]{2}{*}{$5(16.1)$} & \multirow[t]{2}{*}{$1(7.1)$} & \multirow[t]{2}{*}{$0(0.0)$} & \\
\hline - missing data & & & & & \\
\hline
\end{tabular}


Pelvic floor symptoms between the three different levator ani muscle state groups 6-10 weeks after birth (P2)

\begin{tabular}{|c|c|c|c|c|}
\hline Questions & $\begin{array}{l}\text { Intact } \\
\mathrm{n}=161 \\
(75.9 \%)\end{array}$ & $\begin{array}{l}\text { PAV } \\
n=21 \\
(9.9 \%)\end{array}$ & $\begin{array}{l}\text { CAV } \\
n=30 \\
(14.2 \%)\end{array}$ & $\begin{array}{l}\mathrm{p}- \\
\text { value }\end{array}$ \\
\hline 8.) I loose urine involuntary/ against my will & $45(28.0)$ & $7(33.3)$ & $8(26.7)$ & .871 \\
\hline - yes & $116(72.0)$ & $14(66.7)$ & $19(63.3)$ & \\
\hline - no & $0(0.0)$ & $0(0.0)$ & $3(10.0)$ & \\
\hline \multicolumn{5}{|l|}{ - missing data } \\
\hline 9.) Compared to the time before childbirth I lose urine involuntary/against my will & $3(6.7)$ & $1(14.3)$ & $0(0.0)$ & .379 \\
\hline - less often & $25(55.6)$ & $2(28.6)$ & $3(37.5)$ & \\
\hline - unchanged & $15(33.3)$ & $4(57.1)$ & $5(62.5)$ & \\
\hline - more often & $2(4.4)$ & $0(0.0)$ & $0(0.0)$ & \\
\hline \multicolumn{5}{|l|}{ - missing data } \\
\hline 10.) I lose stool involuntary/ against my will & $4(2.5)$ & $1(4.8)$ & $1(3.3)$ & .816 \\
\hline - Yes & $157(97.5)$ & $20(95.2)$ & $27(90.0)$ & \\
\hline - No & $0(0.0)$ & $0(0.0)$ & $2(6.7)$ & \\
\hline \multicolumn{5}{|l|}{ - missing data } \\
\hline 11.) Compared to the time before childbirth I lose stool involuntary/against my will & $2(50.0)$ & $0(0.0)$ & $0(0.0)$ & .558 \\
\hline - less often & $1(25.0)$ & $1(100.0)$ & $1(100.0)$ & \\
\hline - unchanged & $1(25.0)$ & $0(0.0)$ & $0(0.0)$ & \\
\hline - more often & $0(0.0)$ & $0(0.0)$ & $0(0.0)$ & \\
\hline \multicolumn{5}{|l|}{ - missing data } \\
\hline 12.) I lose gas involuntary/ against my will & $39(24.2)$ & $6(28.6)$ & $11(36.7)$ & .254 \\
\hline - Yes & $121(75.2)$ & 15 (71.4) & $17(56.7)$ & \\
\hline - No & $1(0.6)$ & $0(0.0)$ & $2(6.7)$ & \\
\hline \multicolumn{5}{|l|}{ - missing data } \\
\hline 13.) Compared to the time before childbirth I lose gas involuntary/ against my will & $3(7.7)$ & $2(33.3)$ & $0(0)$ & $.003^{*}$ \\
\hline - less often & $32(82.1)$ & $1(16.7)$ & $6(54.5)$ & \\
\hline - unchanged & 4 (10.3) & $3(50)$ & $5(45.5)$ & \\
\hline - more often & $0(0.0)$ & $0(0.0)$ & $0(0.0)$ & \\
\hline \multicolumn{5}{|l|}{ - missing data } \\
\hline 14.) I have a feeling of discomfort/foreign body in the vagina & $19(11.8)$ & $4(19.0)$ & $8(26.7)$ & .061 \\
\hline - Yes & $141(87.6)$ & $17(81.0)$ & $20(66.7)$ & \\
\hline - No & $1(0.6)$ & $0(0.0)$ & $2(6.7)$ & \\
\hline \multicolumn{5}{|l|}{ - missing data } \\
\hline 15.) Compared to the time before childbirth I have a feeling of discomfort/ foreign body in the & $2(10.5)$ & $0(0.0)$ & $0(0.0)$ & .447 \\
\hline - less often & $11(57.9)$ & $2(50.0)$ & $3(37.5)$ & \\
\hline - less often & $5(26.3)$ & $2(50.0)$ & $5(62.5)$ & \\
\hline - unchanged & $1(5.2)$ & $0(0.0)$ & $0(0.0)$ & \\
\hline - missing data & & & & \\
\hline
\end{tabular}




\begin{tabular}{|c|c|c|c|c|}
\hline Questions & $\begin{array}{l}\text { Intact } \\
n=161 \\
(75.9 \%)\end{array}$ & $\begin{array}{l}\text { PAV } \\
n=21 \\
(9.9 \%)\end{array}$ & $\begin{array}{l}\text { CAV } \\
n=30 \\
(14.2 \%)\end{array}$ & $\begin{array}{l}\mathrm{p}- \\
\text { value }\end{array}$ \\
\hline 16.) I have the feeling of something squeezing downwards into the vagina & $25(15.5)$ & $3(14.3)$ & $7(23.3)$ & .469 \\
\hline -Yes & $134(83.2)$ & $17(81.0)$ & $21(70.0)$ & \\
\hline- No & $2(1.2)$ & $1(4.8)$ & $2(6.7)$ & \\
\hline \multicolumn{5}{|l|}{ - missing data } \\
\hline \multirow{5}{*}{$\begin{array}{l}\text { 17.) Compared to the time before childbirth I have the feeling of something squeezing downwards } \\
\text { into the vagina } \\
\text { - less often } \\
\text { - unchanged } \\
\text { - more often } \\
\text { - missing data }\end{array}$} & $4(16.0)$ & $1(33.3)$ & $0(0.0)$ & \multirow[t]{5}{*}{.088} \\
\hline & $13(52.0)$ & $1(33.3)$ & $1(14.3)$ & \\
\hline & $7(28.0)$ & $1(33.3)$ & $6(85.7)$ & \\
\hline & $1(4.0)$ & $0(0.0)$ & $0(0.0)$ & \\
\hline & & & & \\
\hline 18.) Compared to the time before childbirth I have the feeling, that my vaginal opening is & $9(5.6)$ & $1(4.8)$ & $1(3.3)$ & .059 \\
\hline - tighter/closer & $118(73.3)$ & $17(81.0)$ & $15(50.0)$ & \\
\hline - unchanged & $29(18.0)$ & $3(14.3)$ & $12(40.0)$ & \\
\hline - wider & $5(3.1)$ & $0(0.0)$ & $2(6.7)$ & \\
\hline \multicolumn{5}{|l|}{ - missing data } \\
\hline 19.) Compared to the time before childbirth I have the feeling, that my pelvic floor is & $40(24.8)$ & $11(52.4)$ & $17(56.7)$ & \multirow[t]{5}{*}{$.001^{\star}$} \\
\hline - weaker & $106(65.8)$ & $9(42.9)$ & $11(36.7)$ & \\
\hline - unchanged & $8(5.0)$ & $0(0)$ & $0(0)$ & \\
\hline - stronger & $7(4.3)$ & $1(4.8)$ & $2(6.7)$ & \\
\hline \multicolumn{4}{|l|}{ - missing data } & \\
\hline 20.) I do pelvic floor exercise & $103(64.0)$ & $12(57.1)$ & $19(63.3)$ & \multirow[t]{4}{*}{.717} \\
\hline -Yes & $55(34.2)$ & $9(42.9)$ & $9(30.0)$ & \\
\hline - No & $3(1.9)$ & $0(0.0)$ & $2(6.7)$ & \\
\hline \multicolumn{4}{|l|}{ - missing data } & \\
\hline 21.) Compared to the time before delivery, I do pelvic floor exercise & $8(7.8)$ & $4(33.3)$ & $1(5.3)$ & \multirow[t]{5}{*}{.062} \\
\hline - less often & $50(48.5)$ & $5(41.7)$ & $8(42.1)$ & \\
\hline - unchanged & $39(37.9)$ & $3(25.0)$ & $10(52.6)$ & \\
\hline - more often & $6(5.8)$ & $0(0.0)$ & $0(0.0)$ & \\
\hline \multicolumn{4}{|l|}{ - missing data } & \\
\hline 22.) I already had sexual intercourse after delivery & $62(38.5)$ & $8(38.1)$ & $9(30.0)$ & \multirow[t]{4}{*}{.844} \\
\hline -yes & $97(60.2)$ & $12(57.1)$ & $18(60.0)$ & \\
\hline- no & $2(1.2)$ & $1(4.8)$ & $3(10.0)$ & \\
\hline \multicolumn{4}{|l|}{ - missing data } & \\
\hline 23.) Compared to the time before delivery, during sexual intercourse my vagina is & $19(30.6)$ & $5(62.5)$ & $5(55.6)$ & \multirow[t]{5}{*}{.290} \\
\hline - drier & $38(61.3)$ & $3(37.5)$ & $4(44.4)$ & \\
\hline - unchanged & $4(6.5)$ & $0(0.0)$ & $0(0.0)$ & \\
\hline - wetter & $1(1.6)$ & $0(0.0)$ & $0(0.0)$ & \\
\hline - missing data & & & & \\
\hline 24.) Sexual intercourse is painful & $38(61.3)$ & $3(37.5)$ & $4(44.4)$ & \multirow[t]{4}{*}{.285} \\
\hline -Yes & $23(37.1)$ & $5(62.5)$ & $5(55.6)$ & \\
\hline- No & $1(1.6)$ & $0(0.0)$ & $0(0.0)$ & \\
\hline - missing data & & & & \\
\hline
\end{tabular}




\begin{tabular}{|c|c|c|c|c|}
\hline Questions & $\begin{array}{l}\text { Intact } \\
n=161 \\
(75.9 \%)\end{array}$ & $\begin{array}{l}\text { PAV } \\
n=21 \\
(9.9 \%)\end{array}$ & $\begin{array}{l}\text { CAV } \\
n=30 \\
(14.2 \%)\end{array}$ & $\begin{array}{l}\mathrm{p}- \\
\text { value }\end{array}$ \\
\hline 25.) Compared to the time before delivery, sexual intercourse is painful & $0(0.0)$ & $0(0.0)$ & $0(0.0)$ & .537 \\
\hline - less often & $20(52.6)$ & $1(33.3)$ & $3(75.0)$ & \\
\hline - unchanged & $18(47.4)$ & $2(66.7)$ & $1(25.0)$ & \\
\hline $\begin{array}{l}\text { - more often } \\
\text { - missing data }\end{array}$ & $0(0.0)$ & $0(0.0)$ & $0(0.0)$ & \\
\hline 26.) Compared to the time before delivery, my orgasm capability is & $5(8.1)$ & $2(25.0)$ & $3(33.3)$ & .189 \\
\hline - worse & $50(80.6)$ & $6(75.0)$ & $6(66.7)$ & \\
\hline - unchanged & $4(6.5)$ & $0(0.0)$ & $0(0.0)$ & \\
\hline $\begin{array}{l}\text { - better } \\
\text { - missing data }\end{array}$ & $3(4.8)$ & $0(0.0)$ & $0(0.0)$ & \\
\hline 27.) Compared to the time before delivery, my sensation in the vagina during sexual intercourse is & $3(4.8)$ & $0(0.0)$ & $2(22.2)$ & .243 \\
\hline ( & $52(83.9)$ & $8(100.0)$ & $7(77.8)$ & \\
\hline - unchanged & $4(6.5)$ & $0(0.0)$ & $0(0.0)$ & \\
\hline $\begin{array}{l}\text { - increased } \\
\text { - missing data }\end{array}$ & $3(4.8)$ & $0(0.0)$ & $0(0.0)$ & \\
\hline 28.) Compared to the time before delivery, my satisfaction with sexual intercourse is & $8(12.9)$ & $2(25.0)$ & $3(33.3)$ & .524 \\
\hline - reduced & $48(77.4)$ & $6(75.0)$ & $6(66.7)$ & \\
\hline - unchanged & $3(4.8)$ & $0(0.0)$ & $0(0.0)$ & \\
\hline $\begin{array}{l}\text { - increased } \\
\text { - missing data }\end{array}$ & $3(4.8)$ & $0(0.0)$ & $0(0.0)$ & \\
\hline
\end{tabular}




\begin{tabular}{|c|c|c|c|c|}
\hline Questions & $\begin{array}{l}\text { Intact } \\
n=11 \\
(21.6 \%)\end{array}$ & $\begin{array}{l}\text { PAV } \\
n=20 \\
(39.2 \%)\end{array}$ & $\begin{array}{l}\text { CAV } \\
n=20 \\
(39.2 \%)\end{array}$ & p-value \\
\hline 8.) I loose urine involuntary/against my will & $2(18.2)$ & $9(45.0)$ & $8(40.0)$ & .318 \\
\hline -yes & 9 (81.8) & $11(55.0)$ & $12(60.0)$ & \\
\hline- no & $0(0.0)$ & $0(0.0)$ & $0(0.0)$ & \\
\hline \multicolumn{5}{|l|}{ - missing data } \\
\hline 9.) Compared to the time before childbirth I lose urine involuntary/against my will & $0(0.0)$ & $0(0.0)$ & $0(0.0)$ & .445 \\
\hline - less often & $1(50.0)$ & $8(88.9)$ & $6(75.0)$ & \\
\hline - unchanged & $(50.0)$ & $1(11.1)$ & $2(25.0)$ & \\
\hline - more often & $0(0.0)$ & $0(0.0)$ & $0(0.0)$ & \\
\hline \multicolumn{5}{|l|}{ - missing data } \\
\hline 10.) I lose stool involuntary/ against my will & $0(0.0)$ & $1(5.0)$ & $0(0.0)$ & .435 \\
\hline -Yes & $11(100.0)$ & $18(90.0)$ & $20(100.0)$ & \\
\hline - No & $0(0.0)$ & $1(5.0)$ & $0(0.0)$ & \\
\hline \multicolumn{5}{|l|}{ - missing data } \\
\hline 11.) Compared to the time before childbirth I lose stool involuntary/against my will & Not & $0(0.0)$ & Not & Not \\
\hline - less often & & $1(100.0)$ & & \\
\hline - unchanged & & $0(0.0)$ & & \\
\hline - more often & & $0(0.0)$ & & \\
\hline \multicolumn{5}{|l|}{ - missing data } \\
\hline 12.) I lose gas involuntary/ against my will & $2(18.2)$ & $4(20.0)$ & $6(30.0)$ & .678 \\
\hline -Yes & $9(81.8)$ & $16(80.0)$ & $14(70.0)$ & \\
\hline- No & $0(0.0)$ & $0(0.0)$ & $0(0.0)$ & \\
\hline \multicolumn{5}{|l|}{ - missing data } \\
\hline 13.) Compared to the time before childbirth I lose bowel gas involuntary/ against my will & $0(0.0)$ & $1(25.0)$ & $1(16.7)$ & .787 \\
\hline - less often & $2(100.0)$ & $3(75.0)$ & $4(66.7)$ & \\
\hline - unchanged & $0(0.0)$ & $0(0.0)$ & $1(16.7)$ & \\
\hline - more often & $0(0.0)$ & $0(0.0)$ & $0(0.0)$ & \\
\hline \multicolumn{5}{|l|}{ - missing data } \\
\hline 14.) I have a feeling of discomfort/foreign body in the vagina & $1(9.1)$ & $3(15.0)$ & $5(25.0)$ & .498 \\
\hline -Yes & $10(90.1)$ & $17(85.0)$ & $15(75.0)$ & \\
\hline - No & $0(0.0)$ & $0(0.0)$ & $0(0.0)$ & \\
\hline \multicolumn{5}{|l|}{ - missing data } \\
\hline \multirow{2}{*}{$\begin{array}{l}\text { 15.) Compared to the time before childbirth I have a feeling of discomfort/ foreign body in the } \\
\text { vagina }\end{array}$} & $0(0.0)$ & $0(0.0)$ & $0(0.0)$ & .165 \\
\hline & $0(0.0)$ & $3(100.0)$ & $3(60.0)$ & \\
\hline - Iess orten & $1(100.0)$ & $0(0.0)$ & $2(40.0)$ & \\
\hline - unchanged & $0(0.0)$ & $0(0.0)$ & $0(0.0)$ & \\
\hline \multicolumn{5}{|l|}{ - more often } \\
\hline - missing data & & & & \\
\hline
\end{tabular}




\begin{tabular}{|c|c|c|c|c|}
\hline Questions & $\begin{array}{l}\text { Intact } \\
\mathrm{n}=11 \\
(21.6 \%)\end{array}$ & $\begin{array}{l}\text { PAV } \\
n=20 \\
(39.2 \%)\end{array}$ & $\begin{array}{l}\text { CAV } \\
n=20 \\
(39.2 \%)\end{array}$ & p-value \\
\hline $\begin{array}{l}\text { 16.) I have the feeling of something squeezing downwards into the vagina } \\
\text { - Yes } \\
\text { - No } \\
\text { - missing data }\end{array}$ & $\begin{array}{l}2(18.2) \\
9(81.8) \\
0(0.0)\end{array}$ & $\begin{array}{l}2(10.0) \\
18(90.0) \\
0(0.0)\end{array}$ & $\begin{array}{l}7(35.0) \\
13(65.0) \\
0(0.0)\end{array}$ & .150 \\
\hline $\begin{array}{l}\text { 17.) Compared to the time before childbirth I have the feeling of something squeezing } \\
\text { downwards into the vagina } \\
\text { - less often } \\
\text { - unchanged } \\
\text { - more often } \\
\text { - missing data }\end{array}$ & $\begin{array}{l}0(0.0) \\
0(0.0) \\
2(100.0) \\
0(0.0)\end{array}$ & $\begin{array}{l}0(0.0) \\
2(100.0) \\
0(0.0) \\
0(0.0)\end{array}$ & $\begin{array}{l}0(0.0) \\
6(85.7) \\
1(14.3) \\
0(0.0)\end{array}$ & $.035^{\star}$ \\
\hline $\begin{array}{l}\text { 18.) Compared to the time before childbirth I have the feeling, that my vaginal opening is } \\
\text { - tighter/closer } \\
\text { - unchanged } \\
\text { - wider } \\
\text { - missing data }\end{array}$ & $\begin{array}{l}1(9.1) \\
8(72.7) \\
2(18.2) \\
0(0.0)\end{array}$ & $\begin{array}{l}1(5.0) \\
17(85.0) \\
2(10.0) \\
0(0.0)\end{array}$ & $\begin{array}{l}0(0.0) \\
12(60.0) \\
8(40.0) \\
0(0.0)\end{array}$ & .168 \\
\hline $\begin{array}{l}\text { 19.) Compared to the time before childbirth I have the feeling, that my pelvic floor is } \\
\text { - weaker } \\
\text { - unchanged } \\
\text { - stronger } \\
\text { - missing data }\end{array}$ & $\begin{array}{l}1(9.1) \\
10(90.9) \\
0(0.0) \\
0(0.0)\end{array}$ & $\begin{array}{l}5(25.0) \\
14(70.0) \\
1(5.0) \\
0(0.0)\end{array}$ & $\begin{array}{l}10(50.0) \\
10(50.0) \\
0(0.0) \\
0(0.0)\end{array}$ & .107 \\
\hline $\begin{array}{l}\text { 20.) I do pelvic floor exercise } \\
\text { - Yes } \\
\text { - No } \\
\text { - missing data }\end{array}$ & $\begin{array}{l}9(81.2) \\
2(18.8) \\
0(0.0)\end{array}$ & $\begin{array}{l}10(50) \\
10(50) \\
0(0.0)\end{array}$ & $\begin{array}{l}17(85) \\
3(15) \\
0(0.0)\end{array}$ & $.034^{*}$ \\
\hline $\begin{array}{l}\text { 21.) Compared to the time before delivery, I do pelvic floor exercise } \\
\text { - less often } \\
\text { - unchanged } \\
\text { - more often } \\
\text { - missing data }\end{array}$ & $\begin{array}{l}2(22.2) \\
3(33.3) \\
3(33.3) \\
1(11.11)\end{array}$ & $\begin{array}{l}0(0.0) \\
3(30.0) \\
6(60.0) \\
1(10.0)\end{array}$ & $\begin{array}{l}1(5.9) \\
6(35.3) \\
10(58.8) \\
0(0.0)\end{array}$ & .399 \\
\hline $\begin{array}{l}\text { 22.) I already had sexual intercourse after delivery } \\
\text { - yes } \\
\text { - no } \\
\text { - missing data }\end{array}$ & $\begin{array}{l}10(90.9) \\
1(9.1) \\
0(0.0)\end{array}$ & $\begin{array}{l}17(85.0) \\
3(15.0) \\
0(0.0)\end{array}$ & $\begin{array}{l}18(90.0) \\
2(10.0) \\
0(0.0)\end{array}$ & .845 \\
\hline $\begin{array}{l}\text { 23.) Compared to the time before delivery, my vagina is } \\
\text { - drier } \\
\text { - unchanged } \\
\text { - wetter } \\
\text { - missing data }\end{array}$ & $\begin{array}{l}4(40.0) \\
6(60.0) \\
0(0.0) \\
0(0.0)\end{array}$ & $\begin{array}{l}2(11.8) \\
13(76.5) \\
1(5.9) \\
1(5.9)\end{array}$ & $\begin{array}{l}5(27.8) \\
11(61.1) \\
1(5.6) \\
1(5.6)\end{array}$ & .543 \\
\hline $\begin{array}{l}\text { 24.) Sexual intercourse is painful } \\
\text { - Yes } \\
\text { - No } \\
\text { - missing data }\end{array}$ & $\begin{array}{l}3(30.0) \\
6(60.0) \\
1(10.0)\end{array}$ & $\begin{array}{l}4(23.5) \\
13(76.5) \\
0(0.0)\end{array}$ & $\begin{array}{l}6(33.3) \\
10(55.6) \\
2(11.1)\end{array}$ & .676 \\
\hline
\end{tabular}




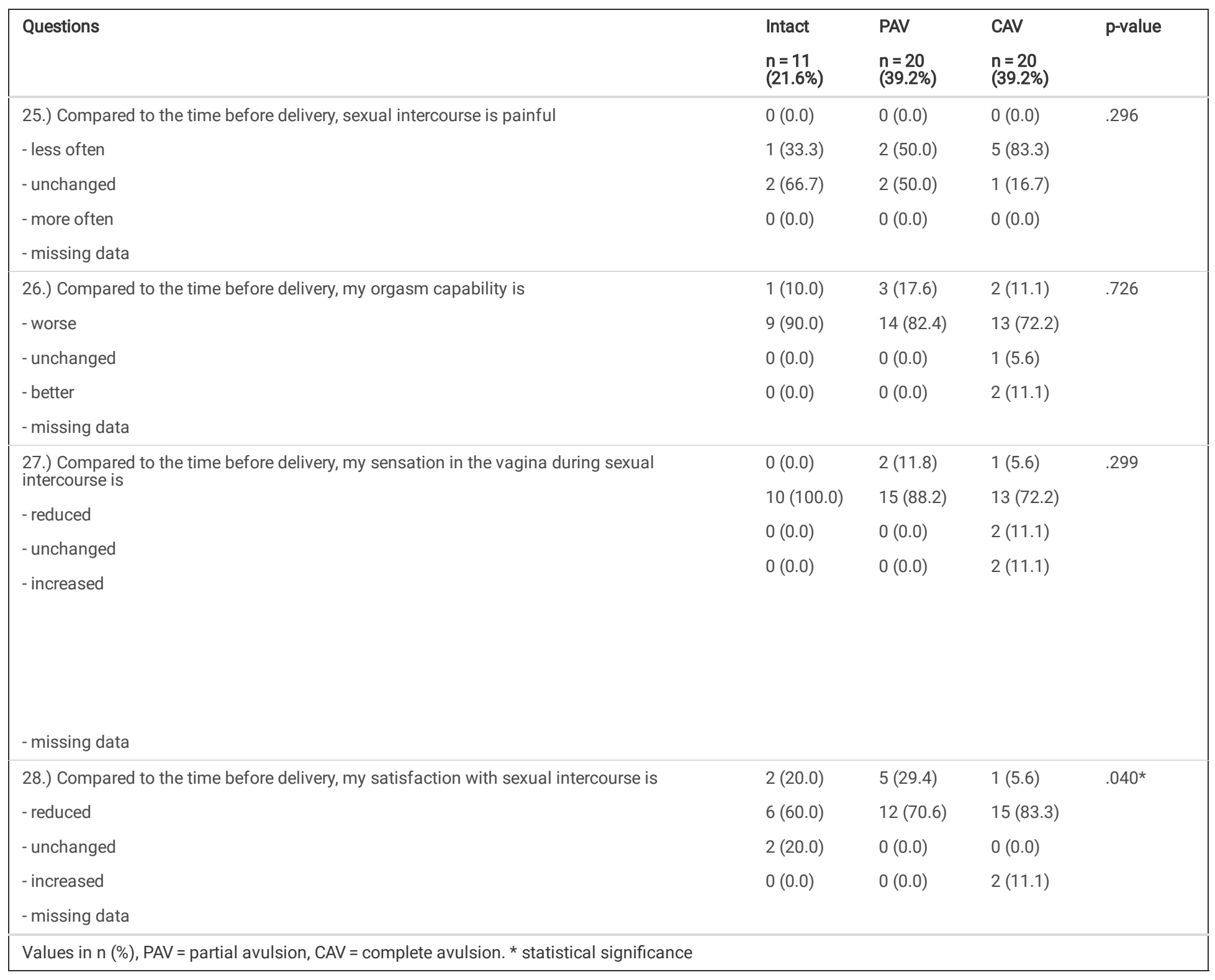

\section{Figures}




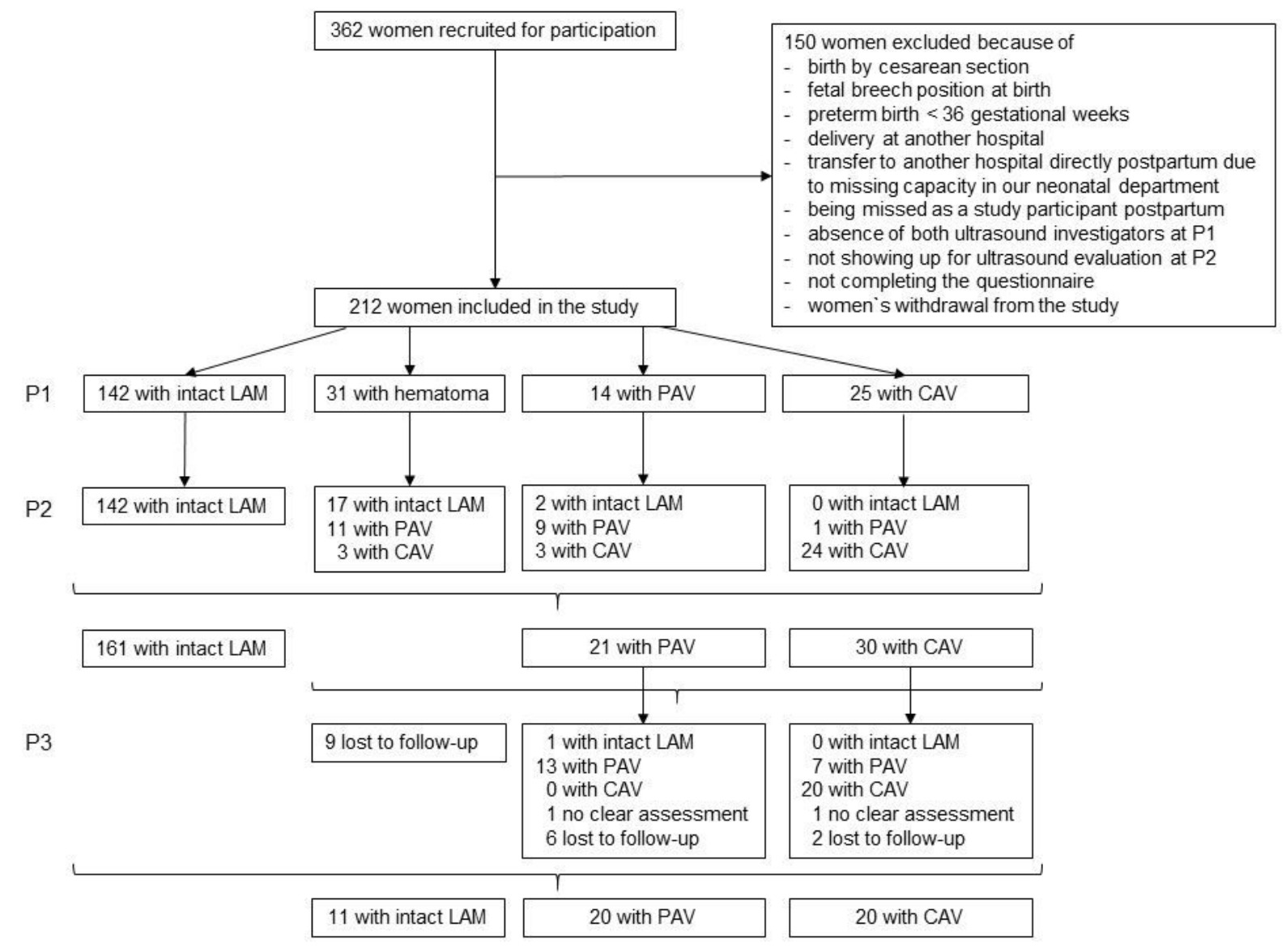

\section{Figure 1}

Study flow chart of the study cohort

\section{Supplementary Files}

This is a list of supplementary files associated with this preprint. Click to download.

- Supp.1Pelvicfloorsymptomsbeforeandduringpregnancy.docx 